Review Article

\title{
Integrated Potato (Solanum Tuberosum L.) Late Blight (Phytophthora Infestans) Disease Management in Ethiopia
}

\section{Yitagesu Tadesse Demissie \\ Department of Plant Pathology, Holeta Agricultural Research Center, Ethiopian Institute of Agricultural Research, Addis Ababa, Ethiopia}

\section{Email address:}

tyitagesu4@gmail.com

\section{To cite this article:}

Yitagesu Tadesse Demissie. Integrated Potato (Solanum Tuberosum L.) Late Blight (Phytophthora Infestans) Disease Management in Ethiopia. American Journal of BioScience. Vol. 7, No. 6, 2019, pp. 123-130. doi: 10.11648/j.ajbio.20190706.16

Received: October 8, 2019; Accepted: November 28, 2019; Published: December 11, 2019

\begin{abstract}
Potato (Solanum tuberosum L.) is the fourth major crop of the world after rice, wheat and maize. Potato is an important crop which holds promise for food to millions of people especially in developing countries. In Ethiopia, the yield per unit area of potato is very low compared to those of other countries. There are many factors that reduce the yield of the crop among which the diseases like late blight (Phytophthora infestans) and bacterial wilt (Ralstonia (Pseudomonas) solanacearum) which play an important role. Diseases such as late blight, early blight, fusarium wilt and black leg primarily affect the crop/foliage whereas diseases such as black scurf, wart, powdery scab and common scab disfigure the tubers and reduce their market value. Major fungal and bacterial diseases affecting potato crop are reviewed here with respect to their identification, symptoms on potato plants or tubers, nature of the pathogen involved, epidemiology, control measures etc. Management of these diseases is therefore very essential. Late blight of potato can be managed using the following management (control) strategies: use of biological control agents, use of resistant varieties, intercropping, use of certified disease-free seed, use of selective fungicides and cultural practices such as destruction of cull piles by freezing or deep burying, destruction of volunteer potato plants in nearby fields throughout the season, destruction (desiccate, disc or flail and desiccate) of infected plants to avoid spread, reduction of periods of leaf wetness and high humidity within the crop canopy by appropriately timing irrigation, application of a recommended fungicide spray program (the program should start prior to the arrival of the pathogen) and desiccation of vines prior to harvest.
\end{abstract}

Keywords: Potato, Late Blight, Integrated Disease Management

\section{Introduction}

Potato (Solanum tuberosum L.) is the fourth major crop of the world [1] after rice, wheat and maize. Some inherent qualities give potato a competitive edge over the leading food crops. In fact, it is able to produce more protein and carbohydrates per unit area than cereals and some leguminous crops like soybeans [2]. The potato plant is attacked by many pathogens causing significant losses to potato producers throughout the world. Bacteria, fungi, viruses, nematodes and phytoplasmas cause serious production constraints [3]. Of the fungal diseases, late blight, caused by Phytophthora infestans, stands out from the rest. This disease is the nightmare of potato producers especially in the coastal wet regions [4-5]. Late blight management programs of 15 sprays per season are not uncommon in wet and cool regions. In Ethiopia, the yield per unit area of potato is very low compared to those of other countries like Rwanda, Egypt and Kenya. There are many factors that reduce the yield of the crop among which the diseases like late blight (Phytophthora infestans), bacterial wilt (Ralstonia (Pseudomonas) solanacearum) and viruses play an important role [6-7].

Late blight of potato, which is caused by Phytophthora infestans (Mont) de Bary is the major bottleneck in potato production in Ethiopia [8] and other parts of the world [9]. It is the best known, highly studied and stills the most destructive of all potato disease. Late blight is probably the single most important disease of potatoes and tomatoes worldwide [10]. Worldwide losses due to late blight are estimated to exceed $\$ 5$ billion annually and thus the pathogen 
is regarded as a threat to global food security [11]. Late blight was responsible for the Irish potato famine in the 1840 s [12]. The disease caused yield losses ranging from $31-100 \%$ in Ethiopia depending on the variety used. Excellent control of the late blight disease was achieved through the use of the phenyl amide fungicides, like Ridomil across the Sub-Saharan Region [13-14]. The best management of late blight and high marginal rate of return was obtained on plots treated with combinations of all tested potato varieties and $0.75 \mathrm{~kg}$ ha-1 Ridomil application followed by $1.5 \mathrm{~kg}$ ha-1 Ridomil application [13].

Integrated pest management (IPM), also known as Integrated Pest Control (IPC) is a broad-based approach that integrates practices for economic control of pests. IPM aims to suppress pest populations below the economic injury level (EIL). The UN's Food and Agriculture Organisation defines IPM as "the careful consideration of all available pest control techniques and subsequent integration of appropriate measures that discourage the development of pest populations and keep pesticides and other interventions to levels that are economically justified and reduce or minimize risks to human health and the environment. IPM emphasizes the growth of a healthy crop with the least possible disruption to agro-ecosystems and encourages natural pest control mechanisms. IPM allows for safer pest control [15]. This includes managing insects, plant pathogens and weeds. Pests and diseases impact on crop yield and quality, and also reduce resource-use efficiency. Improved crop protection strategies to prevent such damage and loss can increase production and make a substantial contribution to food security. Pests and diseases continue to impact on the productivity of crops and quality of crop products worldwide despite many years of research and development on improved methods for their control. It has been estimated that an average of $0 \cdot 20-0 \cdot 30$ of crop yield is lost annually from the field even in crops where pesticides and cultivars with improved genetic resistance to pests and diseases are used [16].

\section{Literature Review}

\subsection{Geographical Distribution and Economic Importance of Potato Late Blight}

Potato late blight is considered to be the most serious potato disease worldwide. It is a very serious economic threat in the vast majority of potato production systems, as well as many tomato production systems worldwide. It is one of the few plant diseases that can absolutely destroy a crop, producing a $100 \%$ crop loss [17]. The disease is also very distractive to tomatoes and some other members of the family solanaceae. Late blight may kill the foliage and stems of potato and tomato plants at any time during the growing season. It also attacks potato tubers and tomato fruits in the field, which rot either in the field or while in storage. It attacks the leaves, stems, and tubers of potato plants [18].

In Ethiopia the disease caused $100 \%$ crop loss on unimproved local cultivar, and $67.1 \%$ on a susceptible variety. Late blight is a major limitation to potato production in high humid elevations; with estimate average yield losses of about $30-75 \%$ on susceptible varieties. According to [19], reports, in Ethiopia late blight of potato causes tuber yield losses of $21.71-45.8 \%$ and $29-57 \%$ depending on the resistance level of the cultivars, respectively. It is the most devastating disease of potato in countries like Ethiopia where subsistence farmers do not know the cause, epidemiology and control of the disease. In Ethiopia the disease occurs throughout the major potato production areas [20].

\subsection{The Pathogen}

The causal organism of potato late blight is Phytophthora infestans (Mont.) de Bary [21]. The genus Phytophthora contains some species (including $\mathrm{P}$. infestans) that are heterothallic (A1 and A2 mating types). Recent studies of Ethiopian isolates found all those tested to date to be A1 mating-type and the Ia mt-DNA-haplotype [22]. P. infestans requires two mating types, $\mathrm{A} 1$ and $\mathrm{A} 2$, to come into contact to produce a sexual spore known as an oospore [23].

\subsection{Genetic Variability}

The possible sources of genetic variation in P. infestans are sexual reproduction, mutation, mitotic recombination, parasexualism, migration, and selection [24-25]. The markers most used to characterize populations of this pathogen have been virulence, mating type, isozymes, mitochondrial haplotypes, restriction fragment length polymorphism (RFLP) and microsatellites (also known as single sequence repeats or SSR) [4, 26-27]. Furthermore, an increasing number of studies based on sequencing of various nuclear or organelle genes have been developed and the full genomes of a number of isolates have been sequenced. Unfortunately, there is no common usage of vocabulary in plant pathology. Within the literature related to $\mathrm{P}$. infestans, and a number of other pathogens as well, the term "virulence" has been used as the genetic ability of a P. infestans race (a particular strain) to overcome host resistance, causing a compatibility reaction, that is, the disease occurs [28]. In many other areas of biology, the term virulence refers to the amount of disease a strain causes (i.e., a quantitative phenomenon). When virulence is used to define the ability to cause disease, the term "aggressiveness" is commonly used to describe the ability of a pathogen isolate to cause more serious disease, i.e., two isolates may be virulent (cause disease) on a potato genotype but one causes more serious disease and is thus more aggressive. Resistance genes ( $\mathrm{R}$ genes) encode products that identify other products in a specific way, especially other products encoded by pathogen avirulence genes. If the $\mathrm{R}$ gene product in a plant recognizes the avirulence gene product of a pathogen, rapid death of plant cells near the infection point occurs and the infection is stopped, i.e., there is no disease. Loss or change of avirulence genes leads to what is often called a compatible reaction and disease occurs. The term race groups isolates based on virulence related to R-genes in 
different potato genotypes. These plants are referred to as "differentials" because they are used to identify the race of a pathogen isolate. Using virulence phenotypes to infer genetic variation in the pathogen population has many constraints because the inference is based on the phenotypic reaction of a pathogen and host without knowing the genetic makeup of either [29].

As noted, two mating types are needed to initiate sexual reproduction in heterothallic species. The discovery of the A2 mating type out of the Toluca valley of Mexico, considered by most researchers as the pathogen's center of origin, was the first evidence of major change in the population of $\mathrm{P}$. infestans worldwide, which until then had only reproduced asexually outside Mexico. Since then, the A2 mating type has been reported world-wide [30-31].

Pathogen resistance to fungicides occurs when certain strains have lower sensitivity than normal to a particular product or class of products. This resistance is the result of stable and hereditary mutations. Resistance to the active ingredient metalaxyl and other phenylamides has been reported in P. infestans populations worldwide, becoming a limiting factor when using this type of fungicides. Temporary reduction in sensitivity to a fungicide is an adaptation trait of the pathogen; however, because it is not hereditary, it can be reverted by changing chemical control strategies. Isozymes are variants of an enzyme with the same or similar catalytic activity. Allozymes are a special type of isozymes in which variants are codified by the same locus. Therefore, they are allelic to one another [32].

\subsection{Development, Epidemiology and Life Cycle of Late Blight}

At temperatures of $13-21^{\circ} \mathrm{C}$, sporangia germinate by means of a single germ tube. Night temperatures of $10-16^{\circ} \mathrm{C}$ accompanied by light rain, fog or heavy dew and followed by days of $16-13{ }^{\circ} \mathrm{C}$ with high relative humidity are ideal for late blight infection and development. The first symptoms of late blight in the field are small, light-to-dark green, and circular-to irregularly-shaped, water-soaked lesions. These usually first appear on the lower leaves where the microclimate is more humid [33]. A zone of white, downy mildew growth 3-5 mm wide appears at the border of the lesions on the undersides of the leaves. Soon entire leaves are infected, die, and become limp. Conditions must remain moist for a minimum of 7-10 hours for spore production to occur. Tubers become infected most often when soils are cool and wet (near field capacity); soil temperatures higher than $18^{\circ} \mathrm{C}$ seem to suppress infections. Because sporangia can survive days or weeks in soil, tubers can become infected for a period of time after infections in the foliage are no longer producing sporangia [34]. P. infestans can survive in living host tissue, such as in seed tubers, cull piles, and volunteer potatoes that over-winter in the field, on other solanaceous plants and in the soil. Sporangia of P. infestans may be spread from infected plants in one field to healthy plants in surrounding fields by wind, splashed rain, mechanical transport and animals [35]. Sporangia of P. infestans germinate either directly with a germ tube or indirectly, by liberating zoospores. Germ tubes can also form secondary sporangia, which may serve to increase the longevity of the spore. Sporangia may germinate at temperatures between 7 and $13^{\circ} \mathrm{C}$ when free water is present on leaves and form 8-12 motile zoospores per sporangium. Encysted zoospores infect leaves by penetrating the leaf surface with a germ tube, either through stomata or by means of direct penetration [36].

\subsection{Economic Importance}

Potato is an important cash crop which gives ready cash to farmers. It is said to be 'complete food' as it contains carbohydrates, proteins, vit. B. vit. C and minerals like $\mathrm{P}, \mathrm{Ca}$ and $\mathrm{Fe}$ required for body growth. It is the richest source of starch. Its calorific value is high. It produces more food per unit area than any cereal crop within short period. In India it is used as vegetable alone or mixed with other vegetables [37-38].

\subsection{Production Constraints}

The potato plant is attacked by many pathogens causing significant losses to potato producers throughout the world. Bacteria, fungi, viruses, nematodes and phytoplasmas cause serious production constraints [39]. In Ethiopia, the yield per unit area of potato is very low compared to those of other countries like Rwanda, Egypt and Kenya. There are many factors that reduce the yield of the crop among which the diseases like late blight (Phytophthora infestans), bacterial wilt (Ralstonia (Pseudomonas) solanacearum) and viruses play an important role [40].

\subsection{Importance and Distribution of Late Blight Pathogen}

Late blight [Phytophthora infestans (Mont.) de Bary] is one of the oldest, most destructive and most serious diseases of the potato. It was first reported from Europe and the United States about 1830 . It became increasingly worse in Western Europe until 1845 when it was responsible for the Irish famine. The disease was so serious in Ireland, where potato constituted the main diet that thousands of people died of starvation. Thousands of others immigrated to the United States, Canada and other countries. Late blight continued to be an extremely serious disease of potato until the accidental discovery of Bordeaux mixture about 40 years later. The fungicide was used widely for many years until more effective and less phototoxic fungicides were developed [41].

Therefore understanding its development, epidemiology and life cycle are most important in selecting and implementing its effective management strategy. There are different types of management options of potato late blight, which can help in reducing its effect. But because of its new strain development, there is no single effective management strategy of late blight of potato in this world. Therefore, adopting integrated disease management (IDM) approach is the most effective, environmentally safe (to both humans and animals), and low costly to the users [42-43]. The use of protectant and systemic fungicides for managing late blight 
has perhaps been the most studied aspect of late blights management in the temperate countries [13, 44-45]. Like many other countries in the world, potato is a very important food and cash crop especially on the highland and mid altitude areas of Ethiopia. Late blight, caused by the oomycete P. infestans, is a devastating disease of potato worldwide. Yield losses due to the disease are attributed to both premature death of foliage and diseased tubers. In Ethiopia, the disease occurs throughout the major potato production areas and it is difficult to produce the crop during the main rainy season without chemical protection measures [20]. Integrating fungicide applications with Varieties by choosing the best fungicide-cultivar combinations improves the durability/sustainability of the released potato varieties in the potato production system. This is particularly important in developing countries such as Ethiopia, where the set-up of efficient and sustainable breeding programs for potatoes are inadequate. Integration of fungicides with cultivars has been commonly practiced for sustainable production of potatoes in most developed world. In tropical Africa, however, fungicide application intervals, frequency of application and timing, and fungicide dose response relationships have not been well investigated [46]. Excellent control of the late blight disease was achieved through the use of the phenyl amide fungicides, like Ridomil across the Sub-Saharan Region [13, 44].

In addition to the benefits of reducing yield losses due to epidemics of late blight, the combined uses of fungicide with resistance varieties can also contribute to reduce the health risks associated with high fungicide applications. Integration of fungicide with potato cultivars could reduce the need of application of high fungicide and able to decrease the risk to human health, environmental contamination, and increase the economic benefit of farmers [47].

\subsection{Sustainable Late Blight Management Approaches}

Effective control of this disease requires implementing an integrated disease management approach. The most important measures are cultural, use of resistant cultivars and chemical controls [39].

\subsubsection{Cultural Control}

Cultural practices are the first line of defense against late blight [42]. Cultural practices can be applied to reduce the pathogen population; by reducing its survival, reproduction, dispersal and penetration of the pathogen. Survival of P. infestans to initiate epidemic can be reduced through avoidance of introducing late blight into a field by planting only disease-free seed tubers, preferably certified seed, destroying all cull and volunteer potatoes, avoid frequent or night-time overhead irrigation and good soil coverage [9]. Late blight is controlled by eliminating cull piles and volunteer potatoes, using proper harvesting and storage practices, and applying fungicides when necessary The cultural measures include: the use of disease free/healthy seed, removal of volunteer potato plants, hilling with adequate amounts of soil and management of plant nutrition [48]. Heavy weed infestations also prevent adequate coverage of potato foliage with fungicides [9]. Since wet conditions are favorable for infection, sprinkler irrigation should be carefully scheduled, or minimized, particularly late in the season when the closed potato canopy provides ideal conditions for late blight development. If possible, rows should be oriented parallel with prevailing winds to encourage better air circulation and foliage drying. After harvest, if tubers are stored, they should be dry when placed in storage, and the storage air temperature and humidity should be managed (Kirk 2009. Scouting all stored potatoes frequently and removing diseased tubers from storage is desirable to prevent disease spread [49].

\subsubsection{Intercropping}

In the central highland of Ethiopia, potato is a garden crop and intercropping with brassica at a lower population being an ordinary practice but crop like garlic is also grown as a sole crop in the same garden. Of the various options available in the high altitudes, cropping systems, other than so many advantages related to intercropping mentioned elsewhere, disease problems is low in an intercropping production systems compared to sole cropping production system [50]. For pathogens like Phytophthora which mostly disperse by wind and rain, interrupting with none host crop for a disease may physically interfere and be able to entrap the spores, thereby reduce the available inoculum [51].

\subsubsection{Host-Plant Resistance}

Host resistance to late blight is of significance in integrated late blight management due to its long-term economic benefits for farmers. It also minimizes changes in the population structure of $\mathrm{P}$. infestans, decreasing the likelihood of fungicide resistance [13, 42]. The use of resistant varieties is among the most effective and environmentally safe means of managing the disease. Thus, breeding for resistance to $\mathrm{P}$. infestans started in the 19th Century and has continued at a slower rate. Biotechnology is also being employed in the pursuit of late blight resistance. Genetically-engineered plants, however, are not acceptable for organic production. Polygenic resistance has proved to be helpful in reducing the amount of fungicides. Cultivars with polygenic resistance have significantly reduced area under disease progress curve (AUDPC) values compared with susceptible ones. Use of resistant varieties is one of the main components of late blight management and is especially effective under tropical conditions [10,52].

Generally resistant potato varieties and improved cultural practices can reduce late blight. Even resistant varieties should be sprayed regularly with fungicides to eliminate, as much as possible, the possibility of becoming suddenly attacked by races of the fungus to which they are not resistant However, it is always advisable to use resistant varieties, even when sprays with fungicides are considered the main control strategy, because resistant varieties delay the onset of the disease or reduce its rate of development so that fewer sprays on a resistant variety may be needed to obtain a satisfactory level of control of the disease $[18,53]$. 
Table 1. Late blight-resistant varieties from CIP population A, which were released in 2002.

\begin{tabular}{lll}
\hline CIP Number & Proposed name & Adaptation \\
\hline 387792.5 & Degemegne & Wide Adaptation \\
384321.9 & Guasa & $\begin{array}{l}\text { Regionally releasefor western } \\
\text { Ethiopia from Adet Research Center }\end{array}$ \\
382173.12 & Gorebela & $\begin{array}{l}\text { Regionally released for North shewa } \\
\text { from Sheno Research Center }\end{array}$ \\
384321.19 & Jalenea & Wide Adaptation \\
\hline
\end{tabular}

\subsubsection{Chemical Control}

At a global level, the major approach to prevent late blight development has been application of fungicides. Protection by fungicides is temporary because they are subject to weathering and breakdown over time [54]. They must be reapplied at certain intervals to protect new growth when disease threatens. Fungicides can slow or stop the development of new symptoms if applied in a timely fashion, but fungicides will not cure existing late blight symptoms [55]. Hence, most fungicides need to be applied before disease occurs or at the first appearance of symptoms to be effective. Generally, few fungicides are effective against pathogens after they have infected a plant [56]. Several broad-spectrum and systemic fungicides are used against potato late blight control. The new strains of the oomycete produced as recombinants of fertilization of the two mating-types (A1 and A2) are resistant to some of the systemic fungicides like, metalaxyl and, therefore, sprays with such materials are ineffective against such strains [31, 57]. The use of fungicides in controlling late blight was found to boost potato yield in Ethiopia. In Ethiopia the first spray with Ridomil MZ $63.5 \% \mathrm{WP}$ at a rate of $2 \mathrm{~kg}$ ha-1 followed by 2-3 sprays (need base application) of Dithane M-45 (mancozeb) at a rate of $3 \mathrm{~kg}$ ha- 1 were found to be effective in controlling late blight. Bekele K. and Hailu B. (2001) had done a research on the efficacy and economics of fungicide spray in the control of late blight of potato in Ethiopia. The result showed that, Ridomil MZ - 63.5\% WP which is both systemic and protectant in action gave the best control (78.8\%). On the other hand Chlorothalonil, Mancozeb and Brestan 10 did not differ significantly in respect to disease control, and gave 59.3, 43.0 and $46.8 \%$ control, respectively. However, the three fungicides significantly $(\mathrm{P}<0.05)$ controlled late blight when compared to the control plot. Binyam et al. [13] also reported that, reduced rates of Ridomil application resulted in better management of potato late blight with the highest marginal rate of return. Despite the fact that fungicide use increases production costs and has negative consequences on environment and human health, the efficacy of fungicides is appealing to resource-poor farmers and fungicide use is a common practice in almost all developing countries. Effective control necessitates multiple applications of fungicides, sometimes as frequently as every 5 days for many diseases [19].

\subsubsection{Biological Control}

Ephrem Debebe et al. [58] had done a research on biocontrol activity of Trichoderma viride and Pseudomonas fluorescens against Phytophthora infestans under greenhouse conditions in Ethiopia. The result, in In vitro antagonism test carried out between $T$. viride and $P$. infestans, showed a radial growth inhibition of the pathogen by $36.7 \%$ and a complete overgrowth of $T$. viride on $P$. infestans later, whereas $P$. fluorescens inhibited the radial growth of the pathogen by $88 \%$. In Foliar spray of the suspensions, $T$. viride was found to be more efficient than $P$. fluorescens and mixed culture. This study revealed that the foliar application of $T$. viride-ES1 has good potential in controlling the late blight disease of potato.

\subsubsection{Integrated Disease Management (IDM)}

Effective management of this disease requires implementation of an integrated disease management approach. Although the most important measures are cultural, resistant cultivars and chemical controls should also be utilized. Integrated pest management has helped farmers drastically reduce the need for chemical controls while increasing production. Effective control of late blight requires implementing an integrated disease management approach. Integration of different management options, including cultural practices (good crop husbandry), resistant varieties and fungicides is required to control late blight. Late blight of potatoes can be controlled successfully by a combination of sanitary measures, resistant varieties, and well-timed or scheduled chemical sprays [18]. In integrated management of disease the host resistance contributes to reducing the number of sprays required to keep late blight below an economic threshold level. The integration of reduced rate of Ridomil application and moderately resistant potato varieties, in the management of potato late blight is very important in reducing environmental pollution and input cost of the fungicide, and increase in production and profitability of high quality potato tuber yield $[13,19]$.

\section{Conclusion and Recommendation}

Potato (Solanum tuberosum L.) is the fourth major crop of the world after rice, wheat and maize. In Ethiopia, the yield per unit area of potato is very low compared to those of other countries. There are many factors that reduce the yield of the crop among which the diseases like late blight (Phytophthora infestans) and bacterial wilt (Ralstonia (Pseudomonas) solanacearum) which play an important role. Major fungal diseases such as late blight, early blight, black scurf, fusarial wilt/dry rot, wart, powdery scab, charcoal rot and major bacterial diseases like soft rot, common scab, bacterial wilt and brown rot cause considerable loss to potato production in field. Diseases such as late blight, early blight, fusarial wilt and black leg primarily affect the crop/foliage whereas diseases such as black scurf, wart, powdery scab and common scab disfigure the tubers and reduce their market value. Some tuber diseases such as dry rots appear mostly in storage while others such as soft rot affect potato tubers at every stage i.e. in field, storage and 
in the transit and may cause substantial loss under certain conditions. Major fungal and bacterial diseases affecting potato crop are reviewed here with respect to their identification, symptoms on potato plants or tubers, nature of the pathogen involved, epidemiology, control measures etc.

Management of these diseases is therefore very essential. In Ethiopia, however, much research has not been done for the management of bacterial wilt disease except identification of bacteria and screening of biological control agents and use of resistant varieties. Late blight of potato can be managed using the following management (control) strategies: use of biological control agents, use of resistant varieties, intercropping, use of certified disease-free seed, use of selective fungicides and cultural practices such as destruction of cull piles by freezing or deep burying, destruction of volunteer potato plants in nearby fields throughout the season, destruction (desiccate, disc or flail and desiccate) of infected plants to avoid spread, reduction of periods of leaf wetness and high humidity within the crop canopy by appropriately timing irrigation, application of a recommended fungicide spray program (the program should start prior to the arrival of the pathogen) and desiccation of vines prior to harvest.

\section{Acknowledgements}

First of all, I would like to thank the Almighty God and St. Marry for making all things possible with their boundless and kind supply of unconditional supports. I would like to deep-heartedly express my affectionate thanks to my beloved wife Bire Kifle Geteneh for her irreplaceable support throughout my life. Thanks to God and the mother of my Lord for making all ups and down possible. I have no word to say anything about my sweet families due to so many support God bless all too.

\section{References}

[1] Prabha, N., Nanda, H. C. and Sharma, S. K., 2018. Genetic Divergence Analysis in Potato (Solanum tuberosum L.). Int. J. Curr. Microbiol. App. Sci, 7 (2), pp. 3152-3157.

[2] Furrer, A. N., Chegeni, M. and Ferruzzi, M. G., 2018. Impact of potato processing on nutrients, phytochemicals, and human health. Critical reviews in food science and nutrition, 58 (1), pp. 146-168.

[3] Kromann, P., Miethbauer, T., Ortiz, O. and Forbes, G. A., 2014. Review of potato biotic constraints and experiences with integrated pest management interventions. In Integrated pest management (pp. 245-268). Springer, Dordrecht.

[4] Fry, W. E., Birch, P. R. J., Judelson, H. S., Grünwald, N. J., Danies, G., Everts, K. L., Gevens, A. J., Gugino, B. K., Johnson, D. A., Johnson, S. B. and McGrath, M. T., 2015. Five reasons to consider Phytophthora infestans a reemerging pathogen. Phytopathology, 105 (7), pp. 966-981.
[5] Runno-Paurson, E., Kiiker, R., Joutsjoki, T. and Hannukkala, A., 2016. High genotypic diversity found among population of Phytophthora infestans collected in Estonia. Fungal biology, 120 (3), pp. 385-392.

[6] Tafesse, S., Damtew, E., van Mierlo, B., Lie, R., Lemaga, B., Sharma, K., Leeuwis, C. and Struik, P. C., 2018. Farmers' knowledge and practices of potato disease management in Ethiopia. NJAS-Wageningen Journal of Life Sciences, 86, pp. 25-38.

[7] Rizvi, A., Zaidi, A., Khan, M. S., Saif, S., Ahmed, B. and Shahid, M., 2017. Growth improvement and management of vegetable diseases by plant growth-promoting rhizobacteria. In Microbial Strategies for Vegetable Production (pp. 99-123). Springer, Cham.

[8] Jimma, E., 2018. Getachew Kebede Tufa.

[9] Goutam, U., Thakur, K., Salaria, N. and Kukreja, S., 2018. Recent Approaches for Late Blight Disease Management of Potato Caused by Phytophthora infestans. In Fungi and their Role in Sustainable Development: Current Perspectives (pp. 311-325). Springer, Singapore.

[10] Chowdappa, P., Nirmal Kumar, B. J., Madhura, S., Mohan Kumar, S. P., Myers, K. L., Fry, W. E. and Cooke, D. E. L., 2015. Severe outbreaks of late blight on potato and tomato in $\mathrm{S}$ outh I ndia caused by recent changes in the $\mathrm{P}$ hytophthora infestans population. Plant Pathology, 64 (1), pp. 191-199.

[11] Newbery, F., Qi, A. and Fitt, B. D., 2016. Modelling impacts of climate change on arable crop diseases: progress, challenges and applications. Current opinion in plant biology, 32, pp. 101-109.

[12] Haverkort, A. J., Boonekamp, P. M., Hutten, R., Jacobsen, E., Lotz, L. A. P., Kessel, G. J. T., Vossen, J. H. and Visser, R. G. F., 2016. Durable late blight resistance in potato through dynamic varieties obtained by cisgenesis: scientific and societal advances in the DuRPh project. Potato Research, 59 (1), pp. 35-66.

[13] Tsedaley, B., 2014. Late blight of potato (Phytophthora infestans) biology, economic importance and its management approaches. Journal of Biology, Agriculture and Healthcare, 4 (25), pp. 215-225.

[14] Subhani, M. N., Sahi, S. T., Hussain, S., Munir, N., Abbas, W. and Bilal, M., 2014. Evaluation of Antifungal Effect of Different Plant Extracts for the Management of Late Blight of Potato Caused by Phytophthorain festans (Mont.) de Bary. Journal of Biologically Active Products from Nature, 4 (2), pp. 125-135.

[15] Mitrev, S., Arsov, E., Kovacevik, B. and Spasov, D., 2017. Integrated pest management (IPM).

[16] Tenkeu, C., 2019. workshop report on IPM Banjul 2019.

[17] Kobayashi, M., Yoshioka, M., Asai, S., Nomura, H., Kuchimura, K., Mori, H., Doke, N. and Yoshioka, H., 2012. StCDPK5 confers resistance to late blight pathogen but increases susceptibility to early blight pathogen in potato via reactive oxygen species burst. New Phytologist, 196 (1), pp. 223-237.

[18] Agrios, G. N., 2005. Plant pathology. Academic press.

[19] Gudero, G., 2017. Integrated Management of Tomato (Solanum Lycopersicum L.) Late Blight [Phytophthora Infestans (Mont.) De Bary] through Host Plant Resistance and Fungicide Application in Gamo Gofa Zone, Southern Ethiopia (Doctoral dissertation, Haramaya University). 
[20] Ayda, T. T., 2015. Effect of Fungicides and Resistant Genotypes on Severity of Potato Late Blight [Phytophthora infestans (Mont.) de Bary] and Yield and Yield Components at Haramaya, Eastern Ethiopia (Doctoral dissertation, Harmaya University).

[21] Akino, S., Takemoto, D. and Hosaka, K., 2014. Phytophthora infestans: a review of past and current studies on potato late blight. Journal of general plant pathology, 80 (1), pp. 24-37.

[22] Meles, J. T. and Hussien, T., 2011. Tuber Yield Loss Assessment of Potato (Solanum tuberosum L.) Varieties due to Late Blight (Phytophthora infestans) and Its Management in Haramaya, Eastern Ethiopia (Doctoral dissertation, Haramaya University).

[23] Montarry, J., Andrivon, D., Glais, I., Corbiere, R., Mialdea, G. and Delmotte, F., 2010. Microsatellite markers reveal two admixed genetic groups and an ongoing displacement within the French population of the invasive plant pathogen Phytophthora infestans. Molecular Ecology, 19 (9), pp. 1965-1977.

[24] Drenth, A., McTaggart, A. R. and Wingfield, B. D., 2019. Fungal clones win the battle, but recombination wins the war. IMA Fungus, 10 (1), p. 18.

[25] Stukenbrock, E. H., 2016. The role of hybridization in the evolution and emergence of new fungal plant pathogens. Phytopathology, 106 (2), pp. 104-112.

[26] Chmielarz, M., Sobkowiak, S., Dębski, K., Cooke, D. E. L., Brurberg, M. B. and Śliwka, J., 2014. Diversity of P hytophthora infestans from P oland. Plant Pathology, 63 (1), pp. 203-211.

[27] Chandra, N. S., Wulff, E. G., Udayashankar, A. C., Nandini, B P., Niranjana, S. R., Mortensen, C. N. and Prakash, H. S., 2011 Prospects of molecular markers in Fusarium species diversity. Applied microbiology and biotechnology, 90 (5), pp. 1625-1639.

[28] Nowicki, M., Foolad, M. R., Nowakowska, M. and Kozik, E. U., 2012. Potato and tomato late blight caused by Phytophthora infestans: an overview of pathology and resistance breeding. Plant Disease, 96 (1), pp. 4-17.

[29] Fry, W., 2008. Phytophthora infestans: the plant (and R gene) destroyer. Molecular plant pathology, 9 (3), pp. 385-402.

[30] Wang, J., Fernández-Pavía, S. P., Larsen, M. M., Garay-Serrano, E., Gregorio-Cipriano, R., Rodríguez-Alvarado, G., Grünwald, N. J. and Goss, E. M., 2017. High levels of diversity and population structure in the potato late blight pathogen at the Mexico centre of origin. Molecular ecology, 26 (4), pp. 1091-1107.

[31] Subhani, M. N., 2016. Phytophthora infestans (Mont.) de Bary (Peronosporales: Pythiaceae): A Review of Life History, Evolutionary Status of Pathogen, Host Range, Mating Types, Symptomology, Disease Cycle, Means of Dispersal, Extent of Losses, and. Journal of Global Agriculture and Ecology, 5 (2), pp. 108-126.

[32] Dekker, J., 2018. The fungicide resistance problem: current status and the role of systemics. Pesticide Interactions in Crop Production: Beneficial and Deleterious Effects, p. 163.

[33] Kirk, H., Dorn, S. and Mazzi, D., 2013. Molecular genetics and genomics generate new insights into invertebrate pest invasions. Evolutionary Applications, 6 (5), pp. 842-856.
[34] Dann, E. K., Ploetz, R. C., Coates, L. M. and Pegg, K. G., 2013. 13 Foliar, Fruit and Soilborne Diseases. The avocado: botany, production and uses, p. 380.

[35] Abewoy, D., 2018. Review on potato late blight and potato tuber moth and their integrated pest management options in Ethiopia.

[36] Tombolato, D. C. M., 2002. Characterization of Isolates of Phytophthora Infestans Collected in Florida in 1999 and 2001 (Doctoral dissertation, University of Florida).

[37] Gitari, H. I., Gachene, C. K., Karanja, N. N., Kamau, S., Nyawade, S., Sharma, K. and Schulte-Geldermann, E., 2018. Optimizing yield and economic returns of rain-fed potato (Solanum tuberosum L.) through water conservation under potato-legume intercropping systems. Agricultural water management, 208, pp. 59-66.

[38] Lutaladio, N. and Castaldi, L., 2009. Potato: The hidden treasure. Journal of Food Composition and Analysis, 22 (6), pp. 491-493.

[39] Guchi, E., 2015. Disease management practice on potato (Solanum tuberosum L.) in Ethiopia. World Journal of Agricultural Research, 3 (1), pp. 34-42.

[40] Atsede, S. R., 2019. Effect of variety tolerance, soil amendment and biological control agents in the management of bacterial wilt (Ralstonia solanacearum) of potato (Solanum tuberosum L.) under field condition in Chencha, Southern Ethiopia (Doctoral dissertation, Addis Ababa University).

[41] Evans, A. and Fenton, B., 2010. A Literature Review of Insecticide and Mineral Oil Use in Preventing the Spread of Non-persistent Viruses in Potato Crops.

[42] Arora, R. K., Sharma, S. and Singh, B. P., 2014. Late blight disease of potato and its management. Potato Journal, 41 (1).

[43] Barzman, M., Bàrberi, P., Birch, A. N. E., Boonekamp, P., Dachbrodt-Saaydeh, S., Graf, B., Hommel, B., Jensen, J. E., Kiss, J., Kudsk, P. and Lamichhane, J. R., 2015. Eight principles of integrated pest management. Agronomy for sustainable development, 35 (4), pp. 1199-1215.

[44] Kefelegn, H., Chala, A., Kassa, B. and Tiwari, G. P. K., 2012. Evaluation of different potato variety and fungicide combinations for the management of potato late blight (Phytophthora infestans) in Southern Ethiopia. International Journal of Life Sciences, 1 (1), pp. 8-15.

[45] Amin, M., Mulugeta, N. and Selvaraj, T., 2013. Field evaluation of new fungicide, Victory $72 \mathrm{WP}$ for management of potato and tomato late blight (Phytophthora infestans (Mont) de Bary) in West Shewa Highland, Oromia, Ethiopia. J. Plant Pathol. Microbiol, 4, p. 192.

[46] Ahmed, N., 2015. Development and Validation of a Disease Predictive Model Based upon Epidemiological Factors for the Management of Late Blight of Potato (Doctoral Dissertation, University of Agriculture, Faisalabad).

[47] Leiminger, J. H. and Hausladen, H., 2012. Early blight control in potato using disease-orientated threshold values. Plant disease, 96 (1), pp. 124-130.

[48] Olanya, O. M., Ojiambo, P. S., Nyankanga, R. O., Honeycutt, C. W. and Kirk, W. W., 2009. Recent developments in managing tuber blight of potato (Solanum tuberosum) caused by Phytophthora infestans. Canadian Journal of Plant Pathology, 31 (3), pp. 280-289. 
[49] Seaman, A., 2016. Organic Production and IPM Guide for Cole Crops.

[50] Belel, M. D., Halim, R. A., Rafii, M. Y. and Saud, H. M., 2014. Intercropping of corn with some selected legumes for improved forage production: A review. Journal of Agricultural Science, 6 (3), p. 48.

[51] Thurston, H. D., 2019. Sustainable practices for plant disease management in traditional farming systems. CRC Press.

[52] Pacilly, F. C., Groot, J. C., Hofstede, G. J., Schaap, B. F. and Van Bueren, E. T. L., 2016. Analysing potato late blight control as a social-ecological system using fuzzy cognitive mapping. Agronomy for sustainable development, 36 (2), p. 35.

[53] Skelsey, P., Rossing, W. A., Kessel, G. J. and van der Werf, W., 2010. Invasion of Phytophthora infestans at the landscape level: how do spatial scale and weather modulate the consequences of spatial heterogeneity in host resistance?. Phytopathology, 100 (11), pp. 1146-1161.
[54] Gupta, S. K. and Thind, T. S., 2018. Disease problems in vegetable production. Scientific Publishers.

[55] Matthews, G., 2015. Pesticides: health, safety and the environment. John Wiley \& Sons.

[56] Nieder, R., Benbi, D. K. and Reichl, F. X., 2018. Health Risks Associated with Pesticides in Soils. In Soil Components and Human Health (pp. 503-573). Springer, Dordrecht.

[57] Tähtjärv, T., 2016. Cultivar resistance and population studies of late blight pathogen in potato breeding in Estonia (Doctoral dissertation, doctoral dissertation. Estonian University of Life Sciences, $156 \mathrm{p}$.

[58] Zegeye, E. D., Santhanam, A., Gorfu, D., Tessera, M. and Kassa, B., 2011. Biocontrol activity of Trichoderma viride and Pseudomonas fluorescens against Phytophthora infestans under greenhouse conditions. Journal of Agricultural Technology, 7 (6), pp. 1589-1602. 